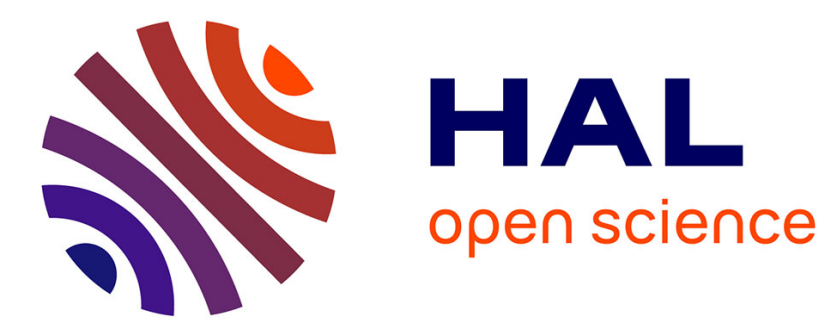

\title{
Laser cladding of copper base alloys onto Al Si7 Mg0.3
}

L. Poire, E. Blank

\section{To cite this version:}

L. Poire, E. Blank. Laser cladding of copper base alloys onto Al Si7 Mg0.3. Journal de Physique IV Proceedings, 1994, 04 (C4), pp.C4-81-C4-84. 10.1051/jp4:1994416 . jpa-00252616

\section{HAL Id: jpa-00252616 https://hal.science/jpa-00252616}

Submitted on 1 Jan 1994

HAL is a multi-disciplinary open access archive for the deposit and dissemination of scientific research documents, whether they are published or not. The documents may come from teaching and research institutions in France or abroad, or from public or private research centers.
L'archive ouverte pluridisciplinaire HAL, est destinée au dépôt et à la diffusion de documents scientifiques de niveau recherche, publiés ou non, émanant des établissements d'enseignement et de recherche français ou étrangers, des laboratoires publics ou privés. 


\title{
Laser cladding of copper base alloys onto Al Si7 Mg0.3
}

\author{
L. POIRE and E. BLANK \\ Centre de Traitement des Matériaux par Laser, Ecole Polytechnique Fédérale de Lausanne, \\ 1015 Lausanne, Switzerland
}

\begin{abstract}
Certain copper alloys have proved to be suitable for laser cladding onto aluminium base. By using the blown powder technique with a $1.5 \mathrm{KW} \mathrm{CO} 2$ laser, clads without cracks or porosity have been produced. The base material has the composition Al Si7 Mg0.3 and the clads are made from alloyed copper with varying contents of $\mathrm{Ni}, \mathrm{Fe}, \mathrm{Si}$ and $\mathrm{Al}$. Aluminium dilution in the clad can be kept lower than $1 \mathrm{wt} \%$. Particularly rough interfaces were observed between the clad material and the remelted zone of the substrate. These interfaces present only narrow and irregular intermetallic areas. Crack free interfaces can be achieved for clads with hardnesses up to $350 \mathrm{HV} 0.1$. Clads, microstructure and interfaces which form in the clad are discussed.
\end{abstract}

\section{Introduction}

Aluminium alloys are used in the aeronautics and automotive industries, particularly because of their low density. However, there are many applications for which these alloys have inadequate mechanical or tribological properties. These properties may be improved by a suitable surface treatment, and here, laser cladding is considered as a means of achieving this improvement.

One feature of aluminium is its ability to form many intermetallic phases with most common elements, such as $\mathrm{Fe}, \mathrm{Ni}, \mathrm{Co}, \mathrm{Cr}, \mathrm{Ti}$, or $\mathrm{Cu}$. In the past, compounds such as $\mathrm{Al}_{3} \mathrm{Ni}_{2}$ and $\mathrm{Al}_{3} \mathrm{Ni}$ [1-4], $\mathrm{Al}_{3} \mathrm{Ti}[4,5], \mathrm{Al}_{7} \mathrm{Cr}$ and $\mathrm{Al}_{11} \mathrm{Cr}_{2}[2,4]$ or $\mathrm{Al}_{3} \mathrm{Fe}$ [4], obtained by laser alloying or cladding have been used to strengthen the surface of aluminium alloys. In this paper, we propose deposition of laser coatings free from aluminium. In order to obtain a metallurgical bond, fusion between clad and substrate is actually required, thus producing an interface zone where there is a gradual change from the substrate composition to the surface composition and where one or more brittle intermetallic layers may be expected. This composition transition zone is susceptible to cracking due to the brittleness of intermetallics and the thermomechanical stresses induced by processing. Therefore, volume and size of highly thermodynamically stable intermetallics such as $\mathrm{NiAl}, \mathrm{CoAl}, \mathrm{Fe}_{3} \mathrm{Al}$, etc., should be minimised, and the interface should be kept distant from the surface experiencing mechanical contact. Copper is found to be a good candidate for this purpose, from an examination of phase diagrams.

\section{Experimental procedure}

The clads were produced by means of the blown powder technique [6] with a $1.5 \mathrm{~kW} \mathrm{CO}_{2}$ laser. The substrates were polished parallelepipedic samples and had the composition $\mathrm{Al} \mathrm{Si} 7$ $\mathrm{Mg0.3}$. Many different powders were injected in varying amounts, so that the composition of clads could be varied. 
Characterization of the clads was carried out using optical microscopy, microprobe analysis and X-ray diffraction techniques. Microstructures were determined by using clads which were remelted and slowly cooled in a furnace and which presented a similar but coarser microstructures compared with those obtained after laser treatment, and which were too fine for the resolution of the microprobe.

\section{Results and discussion}

a - Typical clad

Copper base clads with varying amounts of alloying elements ( $\mathrm{Ni}, \mathrm{Fe}, \mathrm{Si}$ and $\mathrm{Al}$ ) could be produced, pore and crack free, for clad hardnesses up to $350 \mathrm{HV}_{0.1}$. Figure 1 shows a typical clad of copper base alloy on $\mathrm{Al} \mathrm{Si7} \mathrm{Mg0.3.} \mathrm{From} \mathrm{substrate} \mathrm{to} \mathrm{the} \mathrm{surface} \mathrm{of} \mathrm{the} \mathrm{clad} \mathrm{are}$ successively observed a thin remelted zone in the substrate with a refined microstructure, a composition transition layer (hereafter designed as interface) with intermetallic phases, and the clad. The clad has a good composition and hardness homogeneity and presents in this case a very low $\mathrm{Al}$ content (less than $1 \mathrm{wt} \%$ ). The microstructure of this clad is dendritic (figure 2 ), with a primary phase (black) consisting of $\gamma-(\mathrm{Fe}, \mathrm{Ni}, \mathrm{Cu})$ surrounded by a copper solid solution (white).

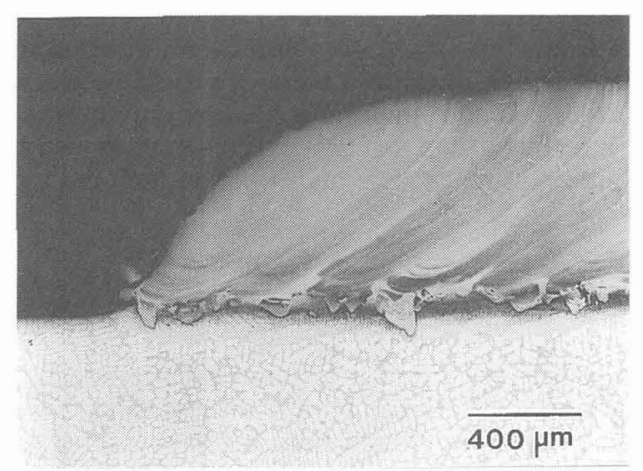

figure 1 : copper base clad onto $\mathrm{Al} \mathrm{Si} 7 \mathrm{Mg} 0.3$

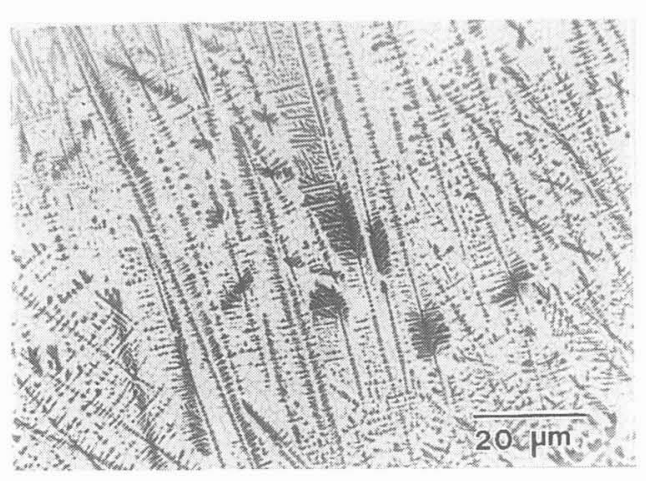

figure $2:$ dendritic microstructure of a copper based clad 
$\mathrm{b}$ - interfaces

The aspect of the interfaces is similar to that described in [7] for the case of Ni-Al bronze cladding onto an aluminium alloy. They are very pertubated and contain narrow and irregular layers of intermetallic phases. This critical zone is intrinsically brittle, as shown by microcracks that can sometimes be observed. However, sound interfaces can be produced. This is illustrated on figure 3 (SEM picture of the interface of the same sample as in figure 1). Microprobe analysis of the compounds wich appear at the interface shows a great variety of compositions with complex $(\mathrm{Ni}, \mathrm{Cu}, \mathrm{Fe}, \mathrm{Al})$ compounds and also $\theta-\mathrm{Al}_{2} \mathrm{Cu}$ phase.

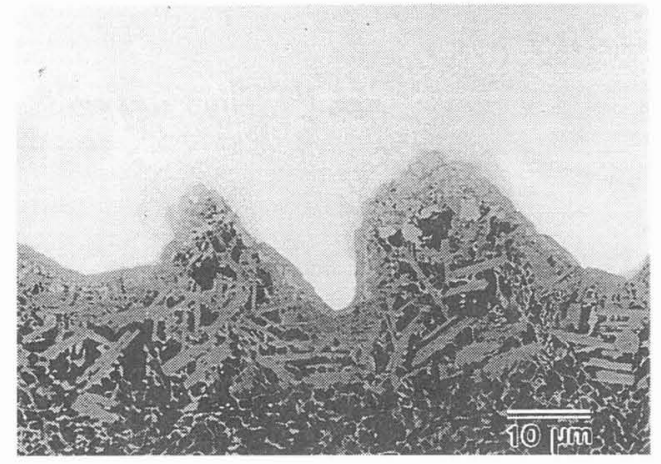

figure 3 : intermetallic phases at the clad/substrate interface. SEM image (back scattered electron).

In the more simple case of a clad containing only $\mathrm{Cu}, \mathrm{Ni}$ and $\mathrm{Al}$ (figure 4), analysis of the interface clearly shows a composition transition with the succession of phases that are predicted by a section of the ternary phase diagram from the clad composition to the substrate composition (figure 5). The effect of Si contained in the substrate has not been taken into account as silicides have not been found in microprobe analysis. The interface in figure 4 can be divided in four zones. Zone $\mathrm{A}$ has a composition similar to that analysed at the clad surface. The $\mathrm{Al}$ content is low (about $3 \mathrm{wt} \%$ ), showing that there is practically no dilution of the $\mathrm{Al}$ base substrate into the clad, especially since in this case, $2.5 \mathrm{wt} \%$ Al was injected. Zone $\mathrm{B}$ is a two-phase zone which is believed to correspond to a demixture in beta phase (dark grey) and a copper ( $\mathrm{Cu}, \mathrm{Ni}, \mathrm{Al}$ ) solid solution (light grey). Zone $\mathrm{C}$ shows platelets having a composition in the $\omega-\mathrm{Al}_{3} \mathrm{Ni}_{2}$ domain. Zone $\mathrm{D}$ is the remelted substrate.



figure 4 : optical micrograph of the interface of a coppernickel clad. 




\section{Conclusion}

Copper alloys are found to be suitable for laser cladding onto AlSi7Mg0.3. Surface materials with almost no aluminium diluted from the substrate can be produced, allowing a substantial modification of the surface properties of aluminium-based industrial components. The inevitable critical zone where intermetallic phases provide the metalurgical transition between substrate and surface materials can be reduced to a thin and irregular layer which is free of pores and microcracks.

\section{References}

[1] E. Gaffet, J.M. Pelletier, S. Bonnet-Jobez, Acta Metall., vol. 37, No 12, 1989, 3205-3215.

[2] E.W. Kreutz, N. Pirch, M. Rozsnoki, Laser treatment of materials, ed. B.L. Mordike, DGM Verl., 1992, 269-279.

[3] P. Sallamand, J.M. Pelletier, Mat. Sc. and Eng., A171, 1993, 263-270.

[4] U. Luft, H.W. Bergmann, B. L. Mordike, Laser treatment of materials, ed. B.L. Mordike, DGM Verl., 1987, 147-161.

[5] K. Uenishi, A. Sugimoto, K. Kobayashi, Z. Metallkd. 83, 1992, 4, 241-245

[6] V.M. Weerasinghe, W.M. Steen, Proc, Conf. Laser in Materials Processing, M.M. Chen et al. ed., ASME, New York, 1983, 15-23.

[7] Y. Liu, J. Mazumder, K. Shibata, proceedings of LAMP'92, Nagaoka, June 1992, vol.2, 813-817.

[8] Chang, Neumann, Mikula, Goldberg, INCRA series of the metallurgy of copper, 1979. 